\title{
Acts of God?
}

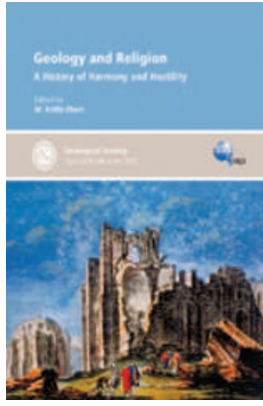

\author{
Geology and \\ Religion: A History \\ of Harmony and \\ Hostility \\ edited by M. Kölbl-Ebert \\ THE GEOLOGICAL \\ SOCIETY OF LONDON: \\ 2009. 368 PP. $€ 95.00$ \\ HARDBACK
}

W hen the earth beneath Lisbon shook on All Saint's Day in 1755, flattening much of the city and causing death on a huge scale, many people in Europe saw it as a consequence of human sinfulness. Contrary to what we might assume today, this was not traditionally the Church's view on earthquakes. Medieval theologians such as Thomas Aquinas wrote extensively about their natural causes, mostly ignoring God's wrath as a factor. And in the aftermath of the Great Lisbon Earthquake, the vitriolic sermons of the Jesuit priest Gabriel Malagrida, denouncing the sins of Lisbon, proved to be too much for the authorities, who felt that they demoralized the survivors. Malagrida was hauled off to prison and ultimately executed by the Portuguese Inquisition.

Still, for many people inside and outside the Church, the horrible event was too overwhelming not to have some kind of underlying moral message. The thinking went that ever since the fall of man had despoiled Eden and brought death into the world, the sins of the human race had been at the root of all the world's troubles - right down to the bedrock.

In Geology and Religion: A History of Harmony and Hostility, science and religion are far from the "non-overlapping magisteria" proposed by Stephen Jay Gould - the relationship between geology and religion is generally neither hostile nor harmonious, but something in between. Readers will find little of the standard history favoured by textbooks and popular science accounts; in fact, the usual stars of the history of geology - Steno, Hutton and Lyell - barely make an appearance. Even Darwin keeps a relatively low profile. Surprisingly, though, these big names aren't missed. Lesser-known figures such as Vallisneri, Betrand, de Luc, Buckman and the hapless Malagrida turn out to be perfectly capable of carrying the tale. Moreover, they are arguably more interesting, because we don't know in advance how their stories turn out.

Contributors to Geology and Religion include geologists, historians and clergymen (some wearing more than one of these hats), and the chapters cover the geological spectrum from seismology and mineralogy to hydrology and glaciology. On the religious end, the Judaeo-Christian tradition is joined by Incan cosmogony, Japanese Shintoism, Buddhism and even (dubiously) Maoism in communist China. But, it is the relationship between historical geology and orthodox Christianity that attracts the most attention.

The chapter by Hugh Torrens captures some of the complexity of this relationship. It carries the title

'James Buckman (1814-1884): The Scientific Career of an English Darwinian Thwarted by Religious Prejudice', but presents a much richer story than this suggests. Buckman's support for Darwin did indeed cause friction between him and the conservative cleric at the head of the agricultural college where he taught, and contributed to his dismissal from the faculty. But the bad blood had begun before Darwinism became an issue, when the cash-strapped college tried to lay claim to Buckman's personal fossil collection, and when he was accused of impropriety while moonlighting as a commercial seed analyst. Doubts about his research on plant transformation were shared by many scientists. Even Darwin quietly removed references to Buckman's experiments from later editions of $\mathrm{On}$ the Origin of Species. So the disharmony here probably had multiple causes.

In another chapter, Martin Rudwick continues an argument that he has made in earlier works: he suggests that during geology's formative years in the seventeenth and eighteenth centuries, Christian theology presented little, if any, impediment to the development of a geological timescale. Instead, the Judaeo-Christian emphasis on a finite timescale for the Earth's existence (as opposed to the eternalist views of other philosophical and religious traditions) helped lay the foundation for geological thinking. The obsession with strict adherence to the biblical timescale is a phenomenon that emerged in the twentieth century in the form of young-Earth creationism.

The growing appeal of creationism, in its young-Earth and other forms, is both puzzling and disturbing. Several of the authors point out that it is no longer solely a North American phenomenon but is spreading worldwide, and that many of its adherents are highly educated.

In what may be the most illuminating chapter of this book, Richard A. Peters, a selfdescribed former young-Earth creationist, offers an explanation for the tenacious grip this doctrine has on the minds (and hearts) of many people whom we might think should know better. As with the question of the Lisbon earthquake (discussed in a chapter by Agustín Udías), it all comes down to human sinfulness and God's righteousness. No death or suffering could have existed before the fall of man; therefore no organisms could have existed for an appreciable length of time before Adam ate the apple. To assert otherwise, even that lowly trilobites lived and died before humans, is to impugn God's mercy over innocent creatures. Not only that, but it also lets wicked humans off the hook. Peters writes that "what unites the radical creationists is a need to declare God innocent of the charge of creating an already fallen world, a world full of suffering and death and futility from the beginning." The issue, then, is not that modern science threatens the idea of God's existence or his power, but that it threatens the idea of his goodness.

This is a tough nut to crack. Addressing the same question in another chapter, Roberts, an Anglican priest and geologist, writes "the existence of suffering, whether through eating apples, or being written into the natural world, is one of the greatest challenges to belief in God." Thus we might surmise that once true believers have latched onto a solution to that moral conundrum, it will probably take more than the (seemingly) self-serving intellectual arguments of scientists to allow them to let it go.

As with other recent volumes on science and religion, Geology and Religion takes us far beyond the discredited 'warfare' thesis proposed by some nineteenth and twentieth century authors, while also avoiding simplistic assertions of harmony between the two realms. As a society, we no longer debate whether earthquakes are signs of God's displeasure with us. But the issue of creationism shows no signs of going away, and it would behoove us to understand why.

\section{REVIEWED BY ALAN CUTLER}

Alan Cutler is with the Carnegie Institution for Science, 1530 P Street NW, Washington DC 20005, USA.

e-mail: acutler@ciw.edu 